\title{
Cikkismertetés: Hogyan befolyásolja a férfiasság a mentális problémákkal kapcsolatos segítségkérést?
}

Article review: How does masculinity relate to men's mental health-seeking behaviour?

Ismertető:

Ismertetett cikk:

Kulcsszavak:

Keywords:

\section{Dolhai Máté}

Gough B, Novikova I. Mental health, men and culture: how do sociocultural constructions of masculinities relate to men's mental health help-seeking behaviour in the WHO European Region? WHO Regional Office for Europe, 2020, Copenhagen (Health Evidence Network synthesis report 70). Elérés:

https://apps.who.int/iris/bitstream/handle/10665/332974/9789289055130-eng.pdf férfiasság; mentális egészség; kultúra; egyenlőtlenségek; viselkedés masculinity; mental health; culture; inequalities; behaviour

Beküldve: 2021. 01. 07., doi: $\underline{10.24365 / \text { ef.v62i3.6107 }}$

\section{BEVEZETÉS}

A férfiak mentális egészsége a népegészségügyön belül, a régióban és globálisan is kulcsfontosságú terület, amelyen javítani kell. Létfontosságú annak jobb megértése, hogy a férfiak miért és hogyan keresnek segítséget pszichés problémáik miatt, ezért fontos, hogy olyan bizonyítékokat vegyünk figyelembe, amelyek az egészség szélesebb körű meghatározó tényezőit foglalják magukban. Ez indokolja a kutatók témaválasztását, ugyanis jelenleg nincs elérhető áttekintő tanulmány az Egészségügyi Világszervezet (World Health Organization, WHO) Európai Régióján belül a férfiasságról alkotott normák (ilyen például az önállóság, függetlenség, vagy az érzelmek kifejezésének nehézsége) és a férfiak pszichés problémáihoz köthető segítségkérő viselkedés kapcsolatáról.

\section{CÉLKITŰZÉS}

A szerzők célja volt áttekinteni azokat az elérhető vizsgálatokat, amelyek arra a kérdésre adnak választ, hogy miképp társulnak a férfiassággal összefüggő normák a férfiak mentálhigiénés segítségkérő viselkedésével. További céljuk volt, hogy a döntéshozóknak ajánlásokat fogalmazzanak meg, milyen módon javíthatják a férfiak mentális jóllétét.

\section{MÓDSZERTAN}

A 2009-2019 között publikált tanulmányok keresését a szerzők 4 kategória kulcsszavainak kombinációjával végezték el angol és orosz nyelven:

1. férfiak (men) vagy férfiasság (masculinity) vagy férfi (male) vagy nem (gender),

2. segítségkérés (help-seeking) vagy elköteleződés (engagement) vagy szolgáltatás igénybevétele (service use),

3. mentális egészség (mental health) vagy depresszió (depression),

4. kultúra (culture).

A keresést a következő adatbázisokon végezték: CINAHL, Project MUSE, PubMed, Scopus and Web of Science, CyberLeninka, eLIBRARY.RU, National Electronic Library, Google Academy (orosz nyelven), General Digital Catalogue of the Russian State Library, Scholar.ru, valamint egyes egyetemi könyvárak adatbázisain (Lomonosov Moscow State University, Higher School of Economics, St Petersburg University). A "szürke" irodalom keresése két nyelven az Ethos, Google és OpenGrey adatbázisokon keresztül történt. Beválasztási kritériumként a gyakori pszichés problémák és segítségkérés, valamint a férfiasságra fókuszáló hangsúly, kizáró kritériumként pedig a címben és absztraktban a szomatikus egészség fókusza, a női nem, a segítségkeresés hiánya, valamint a szövegben súlyosabb pszichés zavarok és a férfiasság hangsúlyának hiánya 
szerepelt. A keresés eredményeként 3197 angol és 399 orosz nyelvű cikket találtak, melyekből 155, illetve 124 került átolvasásra, majd ezekből 41 közleményt válogattak be az áttekintő elemzésbe.

\section{EREDMÉNYEK}

Az elemzés azokat a kulcstémákat hangsúlyozta, amik gátolják vagy támogatják a segítségkérő viselkedést: a hagyományos férfias normák stigmatizálónak tartják a mentális problémákat és az ehhez kapcsolódó segítségkérést, valamint nehezítik a mentális egészségre vonatkozó ismeretszerzés lehetőségét. A normákkal való egyetértés összefüggésben áll a fokozott szerhasználattal és szerabúzussal, valamint csökkenti a segítségkérés valószínűségét. Bizonyos körülmények különösen megnehezítik a férfiak segítségkérő jelzéseit, ilyenek lehetnek a hagyományosan férfias munkahelyek (például a tűzoltóság vagy a katonaság). A tanulmány azt találta, hogy a kisebbségi csoportokhoz tartozó férfiak köztük a menekült és bevándorló, kisebbségi etnikai, őslakos, meleg, biszexuális és vidéki férfiak - körében volt alacsonyabb a segítségkeresés aránya. A segítségkeresés nehézségei általában a kulturális normákhoz (például a mentális betegséggel kapcsolatos családi szégyenérzet), a társadalmi kirekesztéshez, valamint az előítéletekkel és megkülönböztetéssel (például rasszizmus vagy homofóbia) kapcsolatos tapasztalatokhoz kapcsolódtak. A korlátozott egészségmúveltség szintén negatív összefüggésben áll a segítségkérő viselkedéssel. A segítségkérést támogatják az olyan közösségek, ahol az érzelmek kifejezése elfogadott, ilyenek a közeli hozzátartozók csoportjai (például feleség/partner, szülők). Egyre több férfi keres az interneten olyan forrásokat, ahol többet tudhatnak meg a lelki problémákról, emellett egyesek online, anonim módon keresnek segítséget, illetve egyéb bizonyítékok utalnak arra, hogy a férfiakat közismert példaképek ösztönözhetik segítségkérésre. Az áttekintő tanulmány megemlíti, hogy a közelmúltban erőfeszítéseket tettek a nehezen elérhető férfiakat célzó, közösségi szinten szerveződő kezdeményezések kidolgozására: például a házasságuk felbomlása vagy gyászeset után az egyedül élő idősebb férfiak esetében fennállhat a romló mentális egészség és a társadalmi elszigetelődés veszélye. A férfias normákon belül a segítségkérés átkeretezése fokozhatja az intervenciók sikerességét. Az ártalmas, tradicionális férfias szerepek és elképzelések megkérdőjelezése, elhagyása, a férfiak egészségének javulását, valamint a nemi egyenlőség előmozdítását szolgálhatja.

\section{KÖVETKEZTETÉSEK}

Az említett normák, nemi szerepek és sztereotípiák gátolják a férfiakat abban, hogy pszichés problémáikkal segítséget kérjenek, a segítségkérést támogató hatásokat is sikerült azonosítani. Az elmúlt években lezajlott egyfajta szemléletváltás: a férfiasság kizárólagos negatív ábrázolása mellett megjelent a másokkal törődő és egészséges férfikép. A férfiasságról alkotott hagyományos nézetekkel való egyetértés, valamint bizonyos társas tényezők (például előítélet, egyenlőtlenség, szegénység) gátolják a segítségkérő viselkedést. Szükség van egy interdiszciplináris programra, ami irányt mutathat regionális kutatásoknak, amelyek tapasztalatai beépíthetőek a mentális egészséget támogató programokba.

\section{TANULSÁGOK A HAZAI SZAKEMBEREK SZÁMÁRA}

Az idézett tanulmány felhívta a figyelmet, hogy a férfiak segítségkérő viselkedésének szempontjából a tradicionálisan férfias normák akadályként hatnak. Ennek ellenére bizonyos módszerekkel elősegíthetjük a pszichés jóllétüket: ilyen lehet a támogató környezet, ahol a segítségkérés elfogadott. Hasonlóan jótékony, ha a kérést férfiasabb viselkedésként keretezzük. A konvencionálisan férfi normák megkérdőjelezése segíthet a férfiaknak sérülékenységük elfogadásában és bátoríthatja segítségkérésüket.

Információk a szerzőről:

Dolhai Máté, Debreceni Egyetem Népegészségügyi Kar, Debrecen, dolhaimate@gmail.com 